\title{
Autoimmune haematological disorders in two Italian children with Kabuki Syndrome
}

\author{
Paola Giordano ${ }^{*}$, Giuseppe Lassandro, Maria Sangerardi, Maria Felicia Faienza, Federica Valente \\ and Baldassarre Martire
}

\begin{abstract}
Kabuki syndrome (also called Niikawa-Kuroki syndrome) is a rare genetic disease described for the first time in Japan, characterised by anomalies in multiple organ systems and often associated with autoimmune disorders and impaired immune response. We herein report the clinical history, the therapeutic approach and the outcome of two children with Kabuki syndrome who developed autoimmune haematological disorders (haemolytic anaemia and immune thrombocytopenia). Factors regarding differential diagnosis and interventions in better management of this syndrome and its complications are discussed. This is the first report of Italian children with autoimmune haematological disorders complicating Kabuki syndrome.
\end{abstract}

Keywords: Kabuki syndrome, Immune haemolytic anaemia, Immune thrombocytopenia, Autoimmune haematological disorders, KMT2D, MLL2, KDM6A

\section{Background}

The condition named Kabuki make-up syndrome (KS) is a rare multiple anomaly syndrome. The name was attributed because of the facial resemblance to the make-up used in traditional Japanese Kabuki theatre. It was first described in 1981 by Niikawa [1] and Kuroki [2,3]. The estimated prevalence of KS in Japan was 1/32,000 people with almost equal sex distribution. Although it was initially considered as a disease affecting exclusively the Japanese population, several reports support a widespread ethnic distribution of KS [4]. The main clinical characteristics are distinctive facial features: elongated palpebral fissures with eversion of the lateral third of the lower eyelid; arched and broad eyebrows; short columella with depressed nasal tip; large, prominent, or cupped ears. Other findings may include: minor skeletal anomalies, persistence of fetal fingertip pads, from mild to moderate intellectual disability, postnatal growth deficiency, congenital heart defects, genitourinary anomalies, cleft lip and/or palate, gastrointestinal anomalies. Functional differences can include:seizures, endocrinologic abnormalities (premature thelarche in females, feeding problems, hearing loss), hypogammaglobulinemia, increased

\footnotetext{
* Correspondence: paola.giordano@uniba.it

University of Bari "Aldo Moro", Department of Biomedical Sciences and Human Oncology, Paediatric Hospital, Piazza Giulio Cesare, 11 - 70124 Bari,
} Italy

\section{() Biomed Central}

susceptibility to infections and autoimmune disorders as idiopathic thrombocytopenic purpura (ITP), haemolytic anemia, thyroiditis and vitiligo [5,6]. The prevalence of major findings is summarised in the table (Table 1) [7-12]. Genetic basis of KS has been recently elucidated. Mutations in the mixed lineage leukaemia 2 gene, KMT2D (formerly MLL2) mapping on chromosome 12q13.12, are described in $55-80 \%$ of KS patients [13]. KMT2D is a histone H3 lysine 4 (H3K4)-specific methyl transferase that belongs to the SET1 family of human SET-domain protein methyltransferase superfamily. KMT2D acts as a part of multiprotein complex named ASCOM. It interacts with oestrogen receptor- $\alpha$ and it is important for epigenetic transcriptional activation and for embryonic development [14]. KMT2D has emerged as one of the most frequently mutated genes in a variety of cancers, including lymphoma, medulloblastoma and gastric cancer, thus supporting a role as a tumor suppressor in various tissues [15]. In patients without KMT2D mutation, KDM6A gene mutations have been reported. Lederer and Miyake described, respectively, deletion and point mutations as cause of KS $[16,17]$. KDM6A located at Xp11.3 encodes the lysine demethylase $6 \mathrm{~A}$ demethylating di-and trimethyl-lysine 27 on histone H3. Like KMT2D, KDM6A plays an important role in embryogenesis and development [18]. In a recent multicenter study short stature and postnatal growth retardation 
Table 1 The prevalence of major findings in more than 350 individuals with Kabuki syndrome (KS)

\begin{tabular}{ll}
\hline Finding & Prevalence (\%) \\
\hline Typical facial features* & $\sim 95$ \\
Intellectual disability & 92 \\
Hypotonia & $25-89$ \\
Postnatal growth retardation & $35-81$ \\
Joint hypermobility & $50-75$ \\
Feeding difficulties & 70 \\
Congenital heart defects & $40-50$ \\
Premature thelarche & $7-50$ \\
Hearing loss & 40 \\
Seizures & $10-39$ \\
Ocular anomalies & 33 \\
Cleft lip and/or palate & 33 \\
Renal and urinary tract anomalies & 25 \\
Immune dysfunction: & $\sim 20$ \\
Hypogammaglobulinemia, & \\
Idiopathic Thrombocytopenic Purpura (ITP), & \\
Autoimmune haemolytic anemia, & \\
Thyroiditis & \\
Vitiligo &
\end{tabular}

*Elongated palpebral fissures with eversion of the lateral third of the lower eyelid; Arched and broad eyebrows; Short columella with depressed nasal tip and large, Prominent, or cupped ears.

were observed in all individuals with $K D M 6 A$ mutations, but in only half of the group with KMT2D mutations [19]. As KS is a multisystemic disorder, people with KS may require various diagnostic and screening tests, assessments, referrals and multidisciplinary interventions at different stages of their lives [9-12]. For these reasons in 2011, the panel of DYSCERNE team (a network of centres of expertise for dysmorphology), funded by the European Commission Public Health Executive Agency, wrote the "Kabuki Syndrome Clinical Management Guidelines" [20]. These guidelines have been developed using a robust methodology based on the one used by the Scottish Intercollegiate Guidelines Network (SIGN). The method has been adapted to suit rare conditions where the evidence base is limited, and where expert consensus plays a greater role. Of note in the natural history of the KS, an abnormal immune regulation may occur. Some authors reported their experiences in the treatment of KS patients with immunodeficiencies [21] or autoimmune disorders [22]. In this paper, we contribute to the list describing two Italian KS children with autoimmune haematological disorders and their clinical management.

\section{Case 1}

This female patient was diagnosed as KS when she was ten years old through genetic counselling. Her typical facial features were: large and low set ears, elongated palpebral fissures with eversion of the lateral third of the lower eyelid. Additional phenotypic malformations were: brachydactyly $\mathrm{V}$, prominent fingertip pads, muscle hypotonia, joint hyperlaxity, gastroesophageal reflux, left convex scoliosis, moderate mitral stenosis. She was born preterm at $34^{\text {th }}$ weeks of gestational age by caesarean section. In the perinatal period she presented halting weight gain. At the age of three months it was detected a ventricular septal defect (VSD) and a mild aortic coartation, surgically corrected. During her first year of life, a delay of psychomotor development arose. She faced a new heart surgery when she was three years old for aortic decoartation. Screening of KMT2D gene (by PCR amplification of all the 54 exons spanning the KMT2D gene and then by high-throughput sequencing confirming with direct sequencing) [23] didn't find any mutations, otherwise mutation analysis of KDM6A gene has not yet been performed. She was referred to our paediatric haematology unit at the age of eleven for relapsing of chronic immune thrombocytopenia, onset two years earlier and treated with courses of intravenous immunoglobulin and steroid. At this time laboratory investigations revealed: immune haemolytic anaemia ( $\mathrm{Hb} 8.7 \mathrm{~g} / \mathrm{dl}$, direct and indirect Coombs test positive), thrombocytopenia (platelet count 4000/mm [3]) and partial defect of serum IgA levels $(26 \mathrm{mg} / \mathrm{dl})$. She received intravenous immunoglobulin at the dose of $0.8 \mathrm{~g} / \mathrm{Kg}$ for two days in association with metil-prednisolone at the dose $10 \mathrm{mg} / \mathrm{Kg}$ i.v for three days. After tapering steroid therapy, she was discharged with partial haematological remission, ( $\mathrm{Hb} 12.8 \mathrm{~g} / \mathrm{dl}$, Coombs test positive, Plt 13600/mm [3]) and started at home treatment with low dose of prednisone $(2 \mathrm{mg} / \mathrm{Kg} /$ day). In the following years the patient experienced relapsing course of the autoimmune cytopenia which needed to change immunosuppressive therapy with cyclosporine achieving a sustained haematological remission. Nowadays the patient has a resolution of her thrombocytopenia but remains Coombs positive.

\section{Case 2}

This male patient presented hypodontia, lower lip pits, long palpebral fissures, prominent eyelashes, thinning of the central part of the eyebrow, mildly protuberant ears, prominent fingertip pads and hypospadias (Figures 1 and 2). He underwent surgery to correct palatoschisis and ventricular septal defect, at eight and eighteen months of age, respectively. At the age of nine he was admitted to our paediatric haematology unit for leukopenia and thrombocytopenia: his platelet count was $16000 / \mathrm{mm}^{3}$, and white blood cell count $1400 / \mathrm{mm}^{3}$. Serology for viral and microbiological infections was negative. Laboratory investigations revealed normal immunoglobulin levels and positive direct Coombs test. Bone marrow needle aspirate showed normocellular marrow and an increased number of immature 

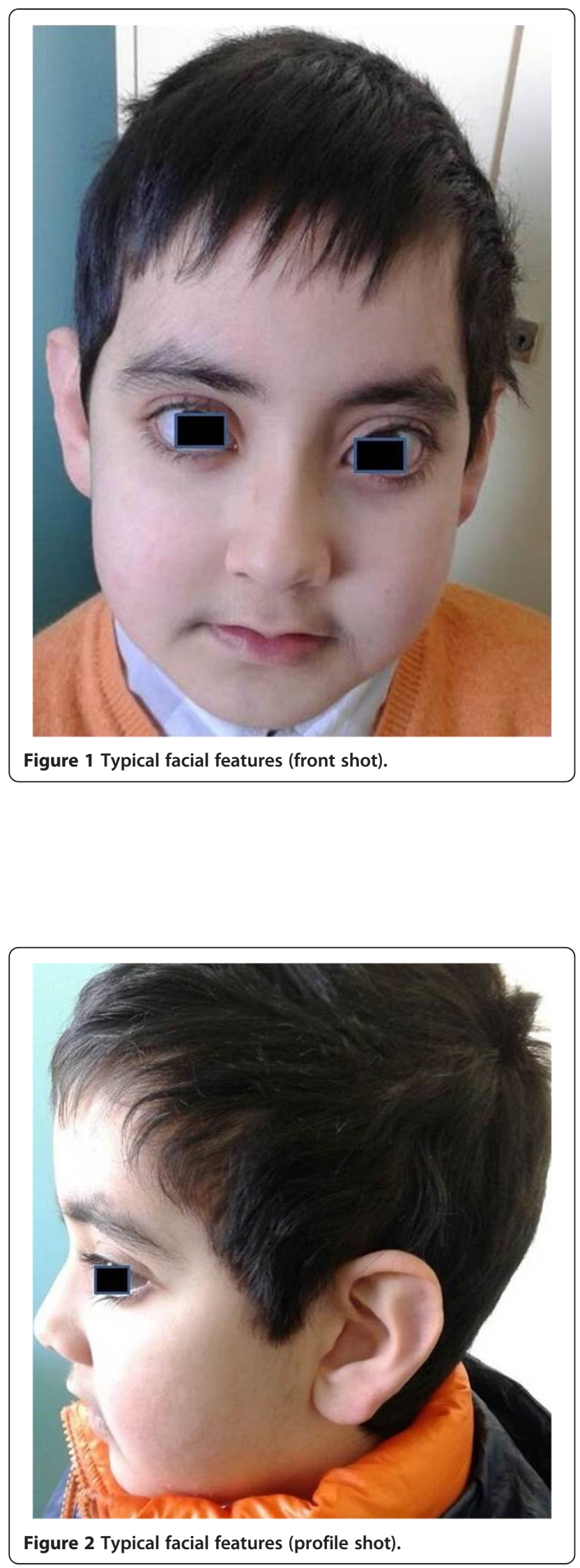

megakariocytes, consistent with the diagnosis of ITP. Fluorescence in situ hybridization assay on bone marrow sample displayed no cytogenetic abnormalities in 7, 8, 21 chromosomes. To evaluate malformation framework, a highthroughput sequencing of $K M T 2 D$ gene [23] was performed. The analysis showed a c. $16384 \mathrm{G}>\mathrm{C}$ heterozygosis sequence variation resulting in the change of aspartic acid with histidine and causing the D5462H mutation. During hospitalisation, the patient received a single intravenous immunoglobulin administration, at the dose of $0.8 \mathrm{~g} / \mathrm{Kg}$, achieving a partial response of platelet count $\left(98000 / \mathrm{mm}^{3}\right)$. He was discharged with steroid home therapy (oral prednisone, $2 \mathrm{mg} / \mathrm{Kg} /$ day and progressive dose reduction in one month). During follow-up, he had a chronic and relapsing course of the autoimmune cytopenia, reason for which the study of lymphocyte apoptosis was carried out. Lymphocyte survival after Fas stimulation resulted normal and also the ratio of double negative (DN) [CD3+ TCR $\alpha \beta+\mathrm{CD} 4-\mathrm{CD} 8-]$ $\mathrm{T}$ cells was within normal values (1\%), thus ruling out an autoimmune lymphoproliferative syndrome (ALPS). Currently, three years after the first observation, the patient still has persistent leukopenia and relapsing episodes of thrombocytopenia, treated with recurrent courses of intravenous immunoglobulin and steroid.

\section{Discussion}

KS is a multiple anomaly/mental retardation syndrome. In 2010, KMT2D was identified as the first causative gene of KS. On the basis of published reports, $55-80 \%$ of KS cases can be explained by mutations in these gene. Recently, also KDM6A deletions and point mutations have been detected in KS patients, however in 20 - 45\% of cases the genetic basis remains unknown. Therefore different authors emphasises the search of additional KS causative genes [24]. This syndrome is sometimes associated with autoimmune abnormalities, such as idiopathic thrombocytopenic purpura (ITP) (from 1.6 to 17\% of cases) [9], autoimmune haemolytic anaemia, leukoplakia, vitiligo and thyroiditis. Since the autoimmune disease does not occur until later childhood, and many of KS reports regard the paediatric age, the real frequency of autoimmune conditions in this syndrome might be underestimated. Moreover, KS patients have increased susceptibility to infection due to immune defects, particularly hypogammaglobulinemia [21]. Of note, the combination of immune deficiency and increased incidence of autoimmune disease has also been observed in patients with DiGeorge Syndrome (DGS) and Common Variable Immune Deficiency (CVID) [25-33]. The DGS is most commonly associated with chromosome 22q11.2 deletion and includes cardiac malformations and facial abnormalities, as well as KS, but also hypoparathyroidsm and T-cell deficiency [34]. On the other hand, the pattern of antibody abnormalities seen in children with KS resembles Common Variable Immune Deficiency (CVID). 
CVID is an heterogeneous immune disorder characterised by failure to properly induce B cell development and an increased incidence of autoimmune disease. Haematological disorders complicating KS have already been described $[10,35]$, but to our knowledge, our cases are the first occurring in paediatric age in Italy. Diagnosis of Kabuki was made on the basis of facial features, confirmed in one case by mutation analysis of KMT2D gene. Since the high prevalence of autoimmune lymphoproliferative syndrome in children with idiopathic autoimmune cytopenias, [36], one out of two patients who had a partial defect of IgA, underwent the study of FAS-mediated apoptosis and the detection of DN lymphocytes. ALPS is a genetic disorder of FAS apoptotic pathway causing autoimmune cytopenia, organomegaly, lymphadenopathy and increased risk of malignancy. Interestingly, the autoimmune cytopenia associated with KS is often chronic. The conventional therapy (intravenous immunoglobulins and steroids) of this condition is often marked by lack of response and relapse of autoimmunity and/or therapy side effects. In particular, Torii et al. [35] showed the successful treatment with Rituximab of refractory idiopathic thrombocytopenic purpura. We treated our cases according the recommendations of Paediatric Oncology and Haematology Italian Association [37] keeping in mind the risk for these patients to develop hypogammaglobulinema [21]. The use of different immunosuppressive protocols, chosen on the experience of each single centre, should lead medical community to standardise therapeutic approaches for KS. Collecting data, concerning a considerable number of patients, about diagnosis, clinical, therapy and outcome might help to improve the management of KS patients as the French registry demonstrates [38]. In addition, due to the underlying immune dysregulation, we suggest to perform a immunologic evaluation at the time of diagnosis, in order to reduce preventable morbidity in these patients.

\section{Consent}

Written informed consent was obtained from the parents of patients for describe these cases report and to publish their pictures. A copy of the written consent is available for review by the Editor-in-Chief of this journal.

\section{Abbreviations}

KS: Kabuki make-up syndrome; VSD: Ventricular sept defect; ITP: Idiopathic thrombocytopenic purpura; CVID: Common variable immune deficiency; DN: Double negative [CD3+ TCRaß + CD4-CD8-] T cells; ALPS: Autoimmune lymphoproliferative syndrome.
}

\section{Competing interests}

The authors declare that they have no competing interests.

\section{Authors' contributions}

$M B$ and $L G$ wrote the draft version. All authors read, revised and approved the manuscript.

Received: 31 August 2013 Accepted: 2 January 2014

Published: 25 January 2014

\section{References}

1. Niikawa N, Maatsuura N, Fukushima Y, Ohsawa T, Kajii T: Kabuki make-up syndrome: a syndrome of mental retardation, unusual facies, large and protruding ears and postnatal growth deficiency. J Pediatr 1981, 99:565-569.

2. Kuroki Y, Suzuki Y, Chyo H, Hata A, Matsui I: A new malformation syndrome of long palpebral fissures, large ears, depressed nasal tip and skeletal anomalies associated with postnatal dwarfism and mental retardation. J Pediatr 1981, 99:570-573.

3. Kuroki Y, Katsumata N, Eguchi T, Fukushima Y, Suwa S, Kajii T: Precocious puberty in Kabuki makeup syndrome. J Pediatr 1987, 110:750-752.

4. Micale L, Augello B, Fusco C, Selicorni A, Loviglio MN, Silengo MC, Reymond A, Gumiero B, Zucchetti F, D'Addetta EV, Belligni E, Calcagnì A, Digilio MC, Dallapiccola B, Faravelli F, Forzano F, Accadia M, Bonfante A, Clementi M, Daolio C, Douzgou S, Ferrari P, Fischetto R, Garavelli L, Lapi E, Mattina T, Melis D, Patricelli MG, Priolo M, Prontera P, et al: Mutation spectrum of MLL2 in a cohort of Kabuki syndrome patients. Orphanet J Rare Dis 2011, 9:6-38.

5. Bokinni Y: Kabuki syndrome revisited. J Human Genet 2012, 57(4):223-227.

6. McGaugharan J, Aftimos S, Jefferies C, Winship I: Clinical phenotypes of nine cases of Kabuki syndrome from New Zealand. Clin Dysmorphol 2001, 10:257-262.

7. Niikawa N, Kuroki Y, Kajii T, Matsuura N, Ishikiriyama S, Tonoki H, Ishikawa N, Yamada Y, Fujita M, Umemoto H: Kabuki make-up (Niikawa-Kuroki) syndrome: a study of 62 patients. Am J Med Genet 1988, 31:565-589.

8. Wilson GN: Thirteen cases of Niikawa-Kuroki syndrome: report and review with emphasis on medical complications and preventative management. Am J Med Genet 1998, 79:112.

9. Kawame H, Hannibal MC, Hudgins L, Pagon RA: Phenotypic spectrum and management issues in Kabuki syndrome. J Pediatr 1999, 134:480-485.

10. Matsumoto N, Niikawa N: Kabuki make-up syndrome: a review. Am J Med Genet C Semin Med Genet 2003, 117:57-65.

11. Armstrong L, Abd El Moneim A, Aleck K, Aughton DJ, Baumann C, Braddock SR, Gillessen-Kaesbach G, Graham JM Jr, Grebe TA, Gripp KW, Hall BD, Hennekam R, Hunter A, Keppler-Noreuil K, Lacombe D, Lin AE, Ming JE, Kokitsu-Nakata NM, Nikkel SM, Philip N, Raas-Rothschild A, Sommer A, Verloes A, Walter C, Wieczorek D, Williams MS, Zackai E, Allanson JE: Further delineation of Kabuki syndrome in 48 well-defined new individuals. Am J Med Genet A 2005, 132:265-272.

12. Schrander-Stumpel CT, Spruyt L, Curfs LM, Defloor T, Schrander JJ, Kabuki syndrome: Clinical data in 20 patients, literature review, and further guidelines for preventive management. Am J Med Genet A 2005, 132A:234-243

13. Banka S, Veeramachaneni R, Reardon W, Howard E, Bunstone S, Ragge N, Parker MJ, Crow YJ, Kerr B, Kingston H, Metcalfe K, Chandler K, Magee A, Stewart F, McConnell VP, Donnelly DE, Berland S, Houge G, Morton JE, Oley C, Revencu N, Park SM, Davies SJ, Fry AE, Lynch SA, Gill H, Schweiger S, Lam WW, Tolmie J, Mohammed SN, et al: How genetically heterogeneous is Kabuki syndrome? MLL2 testing in 116 patients, review, and analyses of mutation and phenotypic spectrum. Eur J Hum Genet 2012, 20:381-388.

14. Dillon S, Zhang X, Trievel R, Cheng $X$ : The SET-domain protein superfamily: protein lysine methyltransferase. Genome Biol 2005, 6:227.

15. Guo C, Chen LH, Huang Y, Chang CC, Wang P, Pirozzi CJ, Qin X, Bao X, Greer PK, McLendon RE, Yan H, Keir ST, Bigner DD, He Y: KMT2D maintains neoplastic cell proliferation and global histone $\mathrm{H} 3$ lysine 4 monomethylation. Oncotarget 2013, 4:2144-2153.

16. Lederer D, Grisart B, Digilio MC, Benoit V, Crespin M, Ghariani SC, Maystadt I, Dallapiccola B, Verellen-Dumoulin C: Deletion of KDM6A, a histone demethylase interacting with MLL2, in three patients with Kabuki syndrome. The Am J Hum Genet 2012, 90:119-124.

17. Miyake N, Mizuno S, Okamoto N, Ohashi H, Shiina M, Ogata K, Tsurusaki Y, Nakashima M, Saitsu H, Niikawa N, Matsumoto N: KDM6A point mutations cause Kabuki syndrome. Hum Mutation 2013, 34:108-110.

18. Lee MG, Villa R, Trojer P, Norman J, Yan KP, Reinberg D, Di Croce L, Shiekhattar R: Demethylation of $\mathrm{H} 3 \mathrm{~K} 27$ regulates polycomb recruitment and $\mathrm{H} 2 \mathrm{~A}$ ubiquitination. Science 2007, 318:447-450.

19. Miyake N, Koshimizu E, Okamoto N, Mizuno S, Ogata T, Nagai T, Kosho T, Ohashi H, Kato M, Sasaki G, Mabe H, Watanabe Y, Yoshino M, Matsuishi T, Takanashi J, Shotelersuk V, Tekin M, Ochi N, Kubota M, Ito N, Ihara K, Hara T, Tonoki H, Ohta T, Saito K, Matsuo M, Urano M, Enokizono T, Sato A, Tanaka $\mathrm{H}$, et al: MLL2 and KDM6A mutations in patients with Kabuki syndrome. Am J Med Genet A 2013, 61:2234-2243. 
20. Clayton-Smith J: Kabuki syndrome clinical management guidelines. http:// kabukisyndrome.com/content/management-kabuki-syndrome.

21. Hoffman JD, Ciprero KL, Sullivan KE, Kaplan PB, McDonald-McGinn DM, Zackai EH, Ming JE: Immune abnormalities are a frequent manifestation of Kabuki syndrome. Am J Med Genet A 2005, 135:278-81.

22. Ming JE, Russel KL, McDonald-McGinn DM, Zackai EH: Autoimmune disorders in Kabuki syndrome. Am J Med Genet A 2005, 132A:260-262.

23. Ng SB, Bigham AW, Buckingham KJ, Hannibal MC, McMillin MJ, Gildersleeve HI, Beck AE, Tabor HK, Cooper GM, Mefford HC, Lee C, Turner EH, Smith JD, Rieder MJ, Yoshiura K, Matsumoto N, Ohta T, Niikawa N, Nickerson DA, Bamshad MJ, Shendure J: Exome sequencing identifies MLL2 mutations as a cause of Kabuki syndrome. Nat Gent 2010, 42:790-793.

24. Priolo M, Micale L, Augello B, Fusco C, Zucchetti F, Prontera P, Paduano V, Biamino E, Selicorni A, Mammì C, Laganà C, Zelante L, Merla G: Absence of deletion and duplication of MLL2 and KDM6A genes in a large cohort of patients with Kabuki syndrome. Mol Genet Metab 2012, 107:627-629.

25. Cunningham-Rundles C: Common variable immunodeficiency. Curr Allergy Asthma Rep 2001, 1:421-429.

26. Gennery AR, Barge D, O'Sullivan JJ, Flood TJ, Abinun M, Cant AJ: Antibody deficiency and autoimmunity in 22q11.2 deletion syndrome. Arch Dis Child 2002, 86:422-425.

27. Jawad AF, McDonald-McGinn DM, Zackai EH, Sullivan KE: Immunological features of chromosome 22q11.2 deletion syndrome. J Pediatr 2001, 139:715-723.

28. Sullivan KE, McDonald-McGinn DM, Driscoll DA, Zmijewski CM, Ellaban AS, Reed L, Emanuel BS, Zackai EH, Athreya BH, Keenan G: Juvenile rheumatoid arthritis-like poltarthritis in chromosome 22q11.2 deletion syndrome. Arthritis Rheum 1997, 40:430-436.

29. DePiero AD, Lourie EM, Berman BW, Robin NH, Zinn AB, Hostoffer RW: Recurrent immune cytopenias in two patients with DiGeorge/ velocardiofacial syndrome. J Pediatr 1997, 131:484-486.

30. Kawame H, Adachi M, Tachibana K, Kurosawa K, Ito F, Gleason MM, Weinzimer S, Levitt-Katz L, Sullivan K, McDonald-McGinn DM: Graves' disease in patients with 22q11.2 deletion. J Pediatr 2001, 139:892-895.

31. Delvecchio M, De Bellis A, De Mattia D, Cavallo L, Martire B: Growth hormone deficiency and antipituitary antibodies in a patient with common variable immunodeficiency. J Endocrinol Invest 2009, 32:637-40.

32. Martire B, Burattini MG, De Santis A, Schettini F Jr, De Mattia D: Benign lymphoproliferation syndrome, autoimmune neutropenia and thrombocytopenia in partial Di George syndrome: efficacy of rh G-CSF and prednisone. Acta Pediatr 2001, 90:821-3.

33. Martire B, Gentile A, Francavilla R, De Santis A, De Mattia D: Successful treatment with cyclosporine A of HCV-driven chronic liver disease mimicking autoimmune hepatitis in a patient with common variable immunodeficiency. Immunopharmacol Immunotoxicol 2005, 27:535-43.

34. Davies GE: Immunodeficiency in DiGeorge syndrome and options for treating cases with complete athymia. Front Immunol 2013, 4:322.

35. Torii $Y$, Yagasaki H, Tanaka H, Mizuno S, Nishio N, Muramatsu H, Hama A, Takahashi Y, Kojima S: Successful treatment with Rituximab of refractory idiopathic thrombocytopenic purpura in a patient with Kabuki syndrome. Int J Hematol 2009, 90:174-6.

36. Seif AE, Manno CS, Sheen C, Grupp SA, Teachey DT: Identifying autoimmune lymphoproliferative syndrome in children with Evans syndrome: a multi-istitutional study. Bloodl 2010, 115:2142-45.

37. Guidelines of paediatric oncology and haematology Italian association. http://www.aieop.org/?q=lineeguida.html.

38. French kabuki syndrome network. Epidemiology, management of patients and research by array-CGH. http://clinicaltrials.gov/show/NCT01314534.

doi:10.1186/1824-7288-40-10

Cite this article as: Giordano et al:: Autoimmune haematological

disorders in two Italian children with Kabuki Syndrome. Italian Journal of Pediatrics 2014 40:10.

\section{Submit your next manuscript to BioMed Central and take full advantage of:}

- Convenient online submission

- Thorough peer review

- No space constraints or color figure charges

- Immediate publication on acceptance

- Inclusion in PubMed, CAS, Scopus and Google Scholar

- Research which is freely available for redistribution 